Utah State University

DigitalCommons@USU

\title{
Home Range Characteristics of Mexican Spotted Owls in the Canyonlands of Utah
}

D. W. Willey

C. Van Riper

Follow this and additional works at: https://digitalcommons.usu.edu/crc_research

Part of the Natural Resources and Conservation Commons

\section{Recommended Citation}

Willey, D. W., \& van Riper, C. (2007). Home range characteristics of Mexican spotted owls in the Canyonlands of Utah. Journal of Raptor Research, 41, 10-15.

This Article is brought to you for free and open access by the Canyonlands Research Center at DigitalCommons@USU. It has been accepted for inclusion in Canyonlands Research Bibliography by an authorized administrator of DigitalCommons@USU. For more information, please contact

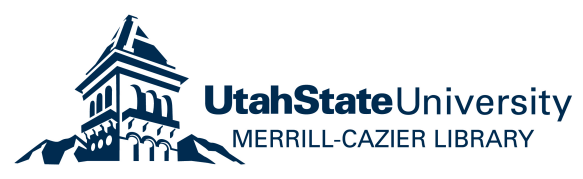




\title{
HOME RANGE CHARACTERISTICS OF MEXICAN SPOTTED OWLS IN THE CANYONLANDS OF UTAH
}

\author{
DAVid W. Willey ${ }^{1}$ AND CHARles VAN Riper III ${ }^{2}$ \\ Montana State University, Department of Ecology, 310 Lewis Hall, Bozeman, MT 59715 U.S.A.
}

\begin{abstract}
We studied home-range characteristics of adult Mexican Spotted Owls (Strix occidentalis lucida) in southern Utah. Twenty-eight adult owls were radio-tracked using a ground-based telemetry system during 1991-95. Five males and eight females molted tail feathers and dropped transmitters within 4 wk. We estimated cumulative home ranges for 15 Spotted Owls (12 males, 3 females). The mean estimate of cumulative home-range size was not statistically different between the minimum convex polygon and adaptive kernel (AK) 95\% isopleth. Both estimators yielded relatively high SD, and male and female range sizes varied widely. For 12 owls tracked during both the breeding and nonbreeding seasons, the mean size of the AK 95\% nonbreeding home range was $49 \%$ larger than the breeding home-range size. The median AK $75 \%$ home-range isopleth (272 ha) we observed was similar in size to Protected Activity Centers (PACs) recommended by a recovery team. Our results lend support to the PAC concept and we support continued use of PACs to conserve Spotted Owl habitat in Utah.
\end{abstract}

KeY Words: Mexican Spotted Owl; Strix occidentalis lucida; canyonlands; habitat; home range; telemetry; Utah.

\section{CARACTERÍSTICAS DEL RANGO DE HOGAR DE STRIX OCCIDENTALIS LUCIDA EN LOS CAÑONES DE UTAH}

\begin{abstract}
Resumen.-Estudiamos las características de los rangos de hogar de adultos de Strix occidentalis lucida en el sur de Utah. Se utilizó un sistema de telemetría terrestre entre los años 1991 y 1995 para seguir a 28 búhos adultos. Cinco machos y ocho hembras mudaron las plumas de la cola y botaron los transmisores en 4 semanas. Estimamos los rangos de hogar acumulativos para 15 búhos (12 machos y 3 hembras). Los estimados promedio de los rangos de hogar acumulativos basados en el método del polígono convexo mínimo y del kernel adaptativo (KA) del $95 \%$ no fueron estadísticamente diferentes. Ambas estimaciones tuvieron una DE relativamente alta y los rangos de los machos y las hembras variaron considerablemente. Para 12 búhos seguidos tanto durante la estación reproductiva como durante la no reproductiva, el tamaño promedio del KA del 95\% durante la época no reproductiva fue un $49 \%$ mayor que el rango de la época reproductiva. La mediana del KA del $75 \%$ (272 ha) que observamos fue similar en tamaño a la de los Centros de Actividad Protegida (CAPs) recomendados por un equipo de recuperación. Nuestros resultados apoyan el concepto de los CAPs y apoyamos el uso continuo de los CAPs para conservar el hábitat de Strix occidentalis lucida en Utah.
\end{abstract}

[Traducción del equipo editorial]

The Mexican Spotted Owl (Strix occidentalis lucida) is distributed among rocky canyonlands and forested highlands in the southwestern United States and northern Mexico (Gutiérrez et al. 1995, Willey 1995). The Mexican Spotted Owl was listed as threatened in 1993 by the U.S. Fish and Wildlife Service due to perceived threats from timber harvest and catastrophic fire (USDI 1995). Although Mexican Spotted Owls are strongly associated with ma-

\footnotetext{
${ }^{1}$ Email address: willey@montana.edu

2 Present address: USGS SBSC Sonoran Desert Research Station, School of Natural Resources, 125 Biological Sciences, University of Arizona, Tucson, AZ 85721 U.S.A.
}

ture mixed-conifer forests (Carey et al. 1992, Forsman et al. 2005) the owl shows considerable variation in habitat affinity across its range (USDI 1995, Ganey et al. 1999, Ganey et al. 2005). Although home-range characteristics have been described for Mexican Spotted Owls in Arizona and New Mexico (Ganey and Balda 1994, Zwank et al. 1994, Ganey et al. 2005), little information is available from the arid and topographically diverse canyonlands of the Colorado Plateau in Utah (Rinkevich and Gutiérrez 1996, Willey 1998).

In southern Utah, the Mexican Spotted Owl inhabits steep sandstone canyons where field observations are difficult; thus, our knowledge of the owl's 
movements and home range in this region is limited (USDI 1995). We investigated home-range characteristics of adult Mexican Spotted Owls within the canyonlands region of southern Utah during 199195. Our objectives were to: (1) estimate the average home-range size used by Spotted Owls; (2) estimate and compare the size of nonbreeding and breeding season home ranges; (3) estimate the size of adaptive kernel (AK) $75 \%$ home-range isopleth to represent areas of concentrated use within owl home ranges (Forsman et al. 2005); and (4) describe vegetation cover types present in home ranges.

\section{Methods}

Study Areas. Our research was conducted in four study areas on the Colorado Plateau (Hintze 1988) in southern Utah: Zion, Capitol Reef, and Canyonlands National Parks, and the Manti-LaSal National Forest (Fig. 1). These areas are included in the High Plateau and Canyonlands subsections of the Colorado Plateau Physiographic region and share similar landscape features (Thornbury 1965, Hintze 1988); for example, the canyonlands are distinguished by entrenched meandering drainages with steep cliffs interrupted by up-warped plateaus, isolated mesas, and laccolithic mountains. Throughout the study areas elevations ranged from 1500-2445 m, annual precipitation averaged $17 \mathrm{~cm} / \mathrm{yr}$, and temperature ranged from $<0^{\circ} \mathrm{C}$ to $>40^{\circ} \mathrm{C}$ (Willey 1998).

The principal floral types found in the canyonlands region included Petran Montane Conifer Forest, Great Basin Desert Scrub, and Great Basin Desert Woodland (Brown 1982, Willey 1998). Desert scrub vegetation was common at hot and arid south-facing slopes and mesa tops at the lower elevations in the region. Scrub vegetation included blackbrush (Coleogyne ramosissima), curl-leaf mahogany (Cercocarpus ledifolius), and Indian ricegrass (Stipa hymenoides). Desert woodland vegetation was dominated by Utah juniper (Juniperus osteosperma) and pinyon pine (Pinus edulis). Desert woodland was the primary vegetation type found in the study areas on south-facing slopes, along arid canyon bottoms, and on mesa tops within the mid-elevations. Riparian vegetation, including included box elder (Acer negundo), bigtooth maple (A. grandidentatum), cottonwood (Populus fremontii), and a variety of Salix species, was present intermittently along canyon bottoms at seeps and springs. At the higher elevations, and on north-facing slopes within the mid-elevations, vegetation included small patches of mixed-conifer forest including Douglas-fir (Pseudotsuga menziesii), white fir (Abies concolor), and ponderosa pine ( $P$. ponderosa).

Capture and Radio-marking. Spotted Owl territories were located within the region during investigation of the owl's distribution and abundance (Willey 1998, Willey and van Riper III 2000). Sites occupied by Spotted Owls were visited during early morning and evening to locate and trap territorial adults near nest and roost sites. A variety of Spotted Owl calls were used to elicit a response to pinpoint an owl's location (Forsman 1983). Owls were captured with bal-chatri traps containing live bait rodents (Gerbillus campestris), and a 3.5-m noose pole. Radio trans-

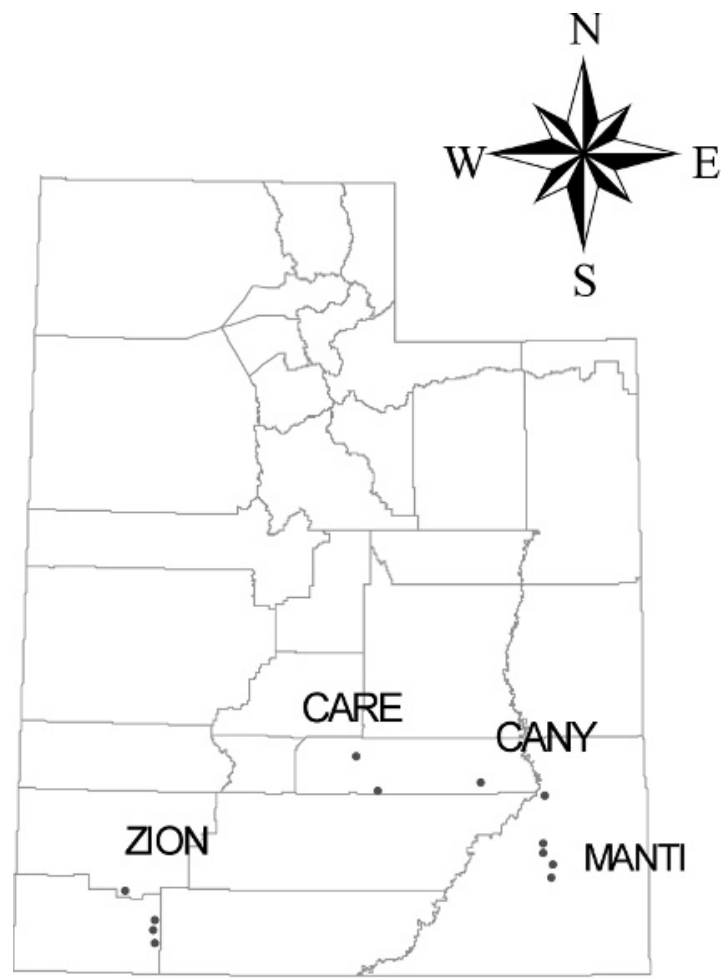

\section{Kilometers}

\section{- Ow Territories Utah Counties}

Figure 1. Four study areas in Utah where Mexican Spotted Owls were studied using radiotelemetry. Points show location of 12 owl territories where telemetry was conducted during 1991-95. Inset shows locations of Utah in the U.S.A. ZION = Zion National Park, CARE = Capital Reef National Park, CANY = Canyonlands National Park, and MANTI $=$ Manti-LaSal National Forest.

mitters (Holohil Inc., Ontario, Canada) weighing 5.5$6.0 \mathrm{gm}$ with an average signal life of $12 \pm 6$ mo, were attached to the two central tail feathers using quick-set epoxy and dental floss.

Sampling Scheme and Radio Triangulation. We used TR1 and TR-2 receivers and handheld $\mathrm{H}$-antennae (Telonics Inc., Mesa, AZ U.S.A.) to estimate Spotted Owl locations. Nocturnal tracking was done on foot from cliff rims above the canyons using headlamps. Nocturnal locations were estimated by simultaneous intersection of compass bearings from $\geq 3$ tracking positions. The standard deviation of bearing error (Nams 1990) was estimated within each study area by taking a series of 20 triangulations from 
tracking stations using three bearings to estimate the location of test transmitters placed throughout owl home ranges (White and Garrott 1990).

Owl locations were estimated using the Maximum Likelihood Lenth Estimator (MLE) developed by Lenth (1981), as modified by Lee et al. (1985), and available within Program LOCATE (Nams 1990). Only owl locations with error ellipses $\leq 15.0$ ha were used for home-range estimates to reduce spatial error.

During nocturnal tracking periods, our goal was to track each owl once per wk, using 4-6 hr sessions rotated between early (sunset to midnight) and late (midnight to sunrise) periods. During each tracking session, we attempted to gain three nocturnal locations per owl tracked, with locations separated by a minimum of $1 \mathrm{hr}$. Further, we conducted diurnal tracking twice per wk for each owl, to attempt to locate roost sites. Although we attempted to keep sampling levels equal among owls and follow our sampling schedule, for various reasons, including weather and transmitter failures, the sampling effort was not even among owls and locations were not obtained for all owls during each tracking week. We attempted to capture owls whose transmitters molted and deploy new transmitters; however, we were not always successful recapturing owls, thus tracking duration varied among owls during the study.

Home-range Estimation. We estimated cumulative and seasonal home ranges with the minimum convex polygon (MCP) and AK methods (Worton 1989, White and Garrott 1990). For estimates of MCP ranges, we used $100 \%$ MCP polygons to represent cumulative home range. For AK estimates, we used AK 95\% isopleth to represent the cumulative home range achieved by individuals. We used the AK $75 \%$ isopleth to represent areas of concentrated use, or activity centers, where owls spent most of their time (Forsman et al. 2005).

Our sampling schedule was designed to minimize autocorrelation (Swihart and Slade 1985) yet Otis and White (1999) suggested autocorrelation is typically not relevant when individual animals are used as the sample unit. Thus, we used all locations for MCP and AK home-range estimates (Forsman et al. 2005). Estimates of cumulative home range were limited to owls with $\geq 50$ relocations, and estimates of seasonal home range was limited to owls with $\geq 10$ relocations per season. We generated all estimates using program TELEM (K. McKelvey, 1993, Program TELEM, USDA Forest Service, Pacific Southwest Research Station, Albany, CA U.S.A.). We stratified locations for each owl between breeding (March-September) and nonbreeding (October-February) periods to contrast seasonal home-range size, basing the dates for home-range seasons on previous observations of breeding activities in the Canyonlands region (Willey 1998). Owl pairs typically began courtship activity during early March, and by the end of September, the majority of juveniles had dispersed from natal areas (Willey and van Riper 2000). The difference in mean home-range size between seasons was evaluated using a paired $t$-test.

Vegetation Cover Types in Home Ranges. We described the different vegetation cover types within each owl's cumulative AK 95\% home range. We assumed the relative abundance of vegetation present within the home range represented some level of habitat selection, but we did not quantify availability, or relative use, of vegetation cover types by the owls. We described cover types present in home ranges by estimating percent cover of desert scrub (scrub), dwarf PJ woodland (PJ), mountain shrub, ponderosa pine, mixed-conifer forest, and riparian using habitat plots. Within each home range, we located 30 random habitat points selected from a 1002-m Universal Trans Mercator projection grid overlaid across each home range delineated by the AK $95 \%$ isopleth. At each of the 30 random habitat points placed in an owl's home range, we established a 50-m radius fixed plot, then used the methods of Brown (1982) to visually estimate the percent cover by desert scrub, desert woodland, riparian, and Petran forest present within the $50 \mathrm{~m}$ plot. Finally, we assigned the plot to the dominant cover type comprising the highest percentage.

\section{RESUlts}

Home-range Size. We captured and radio-marked 28 adults (11 females, 17 males), but 13 owls (8 females, 5 males) molted rectrices within $4 \mathrm{wk}$ of transmitter deployment, thus the sample we used to estimate cumulative ranges included 15 owls (12 males, 3 females). One owl (Oldtexas, Table 1) died after 18 mo of tracking and, although the cause of death was uncertain, a substantial feather pile (with the carcass absent) suggested avian predation. Both Red-tailed Hawks (Buteo jamaicensis) and Great Horned Owls (Bubo virginianus) were observed within this home range during the tracking period.

The mean bearing error derived from error triangulations was $6.5^{\circ}\left( \pm 5.3^{\circ} \mathrm{SD}, N=80\right.$ triangulations). The mean area of confidence ellipses used for estimating owl locations was 5.3 ha $( \pm 4.0 \mathrm{SD}, N$ $=2123$ locations). Mean estimates of cumulative home-range size were not statistically different between MCP and AK 95\% models (Table 1, $t=1.36$, $\mathrm{df}=14, P=0.195)$. However, MCP estimates tended to be larger than AK 95\% estimates. Both types of estimates yielded rather high standard deviations (SD) that were over twice their mean and median estimates. In addition, cumulative size of home ranges for male and female owls varied widely over the course of our study and no clear distinctions between males and females were observed. Although a male owl used the largest home range we measured (2102 ha), the second largest home range (1924 ha) was documented for a female (Table 1).

For 12 owls tracked sufficiently during both breeding and nonbreeding seasons (i.e., $\geq 10$ locations/season), the overall mean cumulative AK 95\% home range was 928 ha (Table 2). The mean size of the AK 95\% nonbreeding home range (1032 ha) 
Table 1. Estimates of cumulative home-range size (ha) for individual Mexican Spotted Owls, Utah, 1991-95. Shown are the $100 \%$ minimum convex polygon (MCP), and the $75 \%$ and $95 \%$ isopleths of the adaptive kernel (AK) home-range models $(N=$ no. locations per owl $)$.

\begin{tabular}{llrrrr}
\hline OwL SITE/SEX & \multicolumn{1}{c}{ TRACKING PERIOD } & $N$ & MCP & AK 95\% & AK 75\% \\
\hline Twin male & 3 June 1994-16 November 1994 & 306 & 1655 & 354 & 155 \\
Spring male & 27 May 1991-15 October 1991 & 184 & 733 & 1012 & 165 \\
Hidden male & 16 June 1991-19 July 1992 & 116 & 2102 & 1151 & 358 \\
Echo male & 21 May 1991-17 November 1992 & 99 & 271 & 120 & 39 \\
Sams male & 19 September 1993-5 October 1994 & 52 & 487 & 505 & 246 \\
First male & 5 February 1991-8 October 1991 & 87 & 670 & 618 & 78 \\
Elephant male & 10 March 1993-20 July 1994 & 102 & 1656 & 2478 & 317 \\
Burro male & 1 March 1994-24 July 1994 & 75 & 273 & 864 & 212 \\
Peavine male & 1 September 1992-15 October 1993 & 55 & 1165 & 1169 & 343 \\
Old Texas male & 7 July 1991-15 March 1992 & 130 & 382 & 174 & 69 \\
New Texas male & 17 May 1994-21 August 1995 & 474 & 1579 & 341 & 180 \\
Dark male & 19 September 1992-23 August 1993 & 151 & 1638 & 852 & 297 \\
Burro female & 20 May 1994-3 October 1995 & 93 & 1025 & 1910 & 576 \\
Hamm female & 25 June 1991-6 September 1991 & 50 & 1528 & 819 & 819 \\
Dark female & 18 September 1994-23 June 1995 & 152 & 1924 & 879 & 334 \\
Mean Size & $\quad \mathbf{1 1 0 2}$ & $\mathbf{9 2 1}$ & $\mathbf{2 8 8}$ & $\mathbf{2 7 2}$ \\
Median Size & $\quad \mathbf{1 0 9 5}$ & $\mathbf{8 5 8}$ & $\mathbf{6 4 1}$ & $\mathbf{2 0 8}$ & \\
Standard & $\quad$ & & & \\
$\quad$ Deviation & & & &
\end{tabular}

was $49 \%$ larger than breeding range size ( 545 ha; $P \leq 0.05,12 \mathrm{df}, t=-4.009$; Table 2). In addition, home-range size varied greatly in both seasons, with the nonbreeding season having the higher SD (Table 2). Furthermore, winter ranges typically included part of the breeding season range plus peripheral areas, and one female moved $35 \mathrm{~km}$ during winter to a distant use area, then returned the following February to the nest area (Table 2). The median size of breeding season home ranges used by all 12 owls in the sample was 374 ha (Table 2), in contrast to 545 ha mean range size.

The patterns of spatial use we observed indicated the owls routinely used focal areas within their home range that may have represented areas of concentrated use (Forsman et al. 2005). For example, during the breeding season, the majority of relocations were centered around nest trees or within frequently-used roost areas. In contrast, winter ranges showed increased use of peripheral areas outside the AK $75 \%$ isopleths. We found that $88 \%$ of all owl locations we observed were located in the canyons below the rims, where terrain was dominated by vertical-walled cliffs. Only $12 \%$ of owl locations were identified outside of canyons on rolling mesas and relatively flat topography.
Vegetation Cover Types in Home Ranges. When averaged across all habitat plots, the PJ woodland was the most common vegetation cover type identified in owl home ranges. $\mathrm{PJ}$ was present at $42 \%$ of 450 plots visited across all home ranges and represented the dominant cover type. Mixed conifer forest was present at only $31 \%$ of random plots. Desert scrub vegetation was present at $17 \%$ of plots, and deciduous riparian vegetation was present at $10 \%$ of plots. Thus nearly $60 \%$ of habitat plots located in home ranges supported arid scrub or PJ habitats. Individual owls showed distinct seasonal changes in use of cover types. For example, one female migrated during winter from a nest area in mixed-conifer forest to a relatively high-elevation $(2900 \mathrm{~m})$ area dominated by stands of Engelmann spruce ( $P i$ cea engelmannii). A male moved from a nest area dominated by riparian vegetation to winter in desert scrub habitat. Both owls returned to their previous breeding areas the following February.

\section{Discussion}

Our study presents the first description of adult Mexican Spotted Owl home ranges from southern Utah's canyonlands. The cumulative home ranges we observed were among the largest described for 
Table 2. Seasonal adaptive kernel $95 \%$ isopleth home-range size estimates (ha) for 12 Mexican spotted owls tracked in Utah during 1991-95. The breeding season was March-September, and nonbreeding season from October-February. $N$ represents the number of locations per owl.

\begin{tabular}{|c|c|c|c|c|}
\hline \multirow[b]{2}{*}{ Owl Site/Sex } & \multicolumn{4}{|c|}{ Home Ranges By AdaPtive KeRnel 95\% IsOPleth (ha) } \\
\hline & Breeding SEASON & $N$ & NonbreEding SEASON & $N$ \\
\hline Twin male & 116 & 268 & 809 & 38 \\
\hline Spring male & 294 & 162 & 462 & 22 \\
\hline Sams male & 166 & 146 & 763 & 20 \\
\hline Peavine male & 383 & 28 & 1012 & 27 \\
\hline Elephant male & 366 & 72 & 1594 & 30 \\
\hline New Texas male & 873 & 437 & 1294 & 37 \\
\hline Hidden male & 735 & 92 & 520 & 24 \\
\hline First male & 253 & 61 & 771 & 26 \\
\hline Echo male & 75 & 89 & 135 & 10 \\
\hline Dark male & 423 & 136 & 1690 & 15 \\
\hline Dark female & 945 & 131 & 788 & 21 \\
\hline Burro female & 1918 & 82 & 2549 & 11 \\
\hline Means & $545^{a}$ & & $1032^{a}$ & \\
\hline Medians & 374 & & 798 & \\
\hline Standard Deviation & 518 & & 657 & \\
\hline
\end{tabular}

a Significantly different $P \leq 0.05$, df $=12$, paired $t$-test.

Spotted Owls, but comparisons among regions are confounded by differences in methods and tracking periods. Home-range size estimated in our study (mean cumulative $=928$ ha) was similar in size to cumulative home ranges in Arizona reported by Ganey et al. (1999; mean $=895$ ha), but larger than cumulative home ranges reported for Spotted Owls in New Mexico (365 ha, Zwank et al. 1994). Cumulative Northern Spotted Owl ( $S$. o. caurina) home ranges in Washington (mean $=4972$ ha, Forsman et al. 2005) were much larger than those we estimated in southern Utah; thus Spotted Owl home-range size varies widely among regions (Forsman et al. 2005, Ganey et al. 2005).

Home-range size for Spotted Owls appears to be associated with various factors, including elevation and region (Ganey et al. 2005), habitat complexity (Willey 1998), distribution of mature forest (Carey et al. 1992), and distribution and abundance of prey (Carey et al. 1992).

In southern Utah, our contrast of seasonal homerange size indicated that movements during the nonbreeding season, particularly during the fall, accounted, in part, for variation observed in homerange size among individuals; however, further research is needed to explore the influence of movements between ranges on home-range size. While many of the owls we tracked remained close to their breeding sites year round, others moved up to
$35 \mathrm{~km}$ from the nest area during the nonbreeding season (Willey 1998). Although long-distance movements are rare for Spotted Owls (but see Gutiérrez et al. 1995), movements to peripheral areas in the nonbreeding season have been documented in other studies (Forsman et al. 2005) and were typical of Spotted Owls in Utah (Willey 1998).

We found that Spotted Owls were frequently observed within cliff terrain below canyon rims, where landscapes were dominated by steep cliffs that contrasted sharply with the flat and rolling topography found on rims and plateaus. Rinkevich and Gutiérrez (1996) reported similar use of rugged canyons for Spotted Owls observed in Zion National Park.

Our results for home-range characteristics may help focus management efforts in Utah on arid rocky canyon environments that contrast sharply with more mature forests typically cited as Spotted Owl habitat (Carey et al. 1992, USDI 1995, Ganey et al. 2005). Furthermore, the Mexican Spotted Owl recovery plan (USDI 1995) recommended protecting 243-ha "protected activity centers" (PACs) around occupied nest and roost areas. Those guidelines were based on analysis of median sizes of AK $75 \%$ isopleths from Spotted Owls in Arizona (USDI 1995). Our estimated median AK $75 \%$ isopleths (272 ha, Table 1) were quite similar to results presented in the Mexican Spotted Owl Recovery Plan (i.e., 243 ha PACs). Given that PACs were intended 
to focus protection on the areas most important to owls, we think our results lend further support to the Recovery Plan's recommendation and we support continued use of PACs to conserve Spotted Owl habitat in Utah.

\section{ACKNOWLEDGMENTS}

We thank the numerous field assistants who worked on the project; in particular, Jon Nelson, Randolph Skrovan, and Frank LaSorte did yeoman duty throughout the study. Sarah Rinkevich, Frank Howe, Alan Franklin, Pat "Ranger" Ward, and Joe Ganey assisted with trapping and their help and insights were greatly appreciated. We thank William Block, USDA Forest Service, Rocky Mountain Research Station, Flagstaff, AZ, and Frank Howe, Utah Division of Wildlife Resources, who provided significant funding and excellent logistical support throughout the research. Reviews of the manuscript by Eric Forsman, Joseph Ganey, and Joseph Buchanan greatly improved early drafts of the paper.

\section{Literature Cited}

BRown, D.E. 1982. Biotic communities of the American southwest-United States and Mexico. Desert Plants $4: 1-57$.

Carey, A.B., S.P. Horton, And B.L. Biswell. 1992. Northern Spotted Owls: influence of prey base and landscape character. Ecol. Monogr. 62:223-250.

ForsmAN, E.D. 1983. Methods and materials for locating and studying Spotted Owls. USDA Gen. Tech. Rep. PNW-162, Portland, OR U.S.A.

—, T.J. Kaminsky, J.C. Lewis, K.J. Maurice, and S.G. SOVERN. 2005. Home range and habitat use of Northern Spotted Owls on the Olympic Peninsula, Washington. J. Raptor Res. 39:365-377.

GANEY, J.L. AND R.P. BALDA. 1994. Habitat selection by Mexican Spotted Owls in northern Arizona. Auk 111:162-169.

- W.M. Block, J.S. Jenness, And R.A. Wilson. 1999. Mexican Spotted Owl home range and habitat use in pine-oak forest: implications for forest management. For. Sci. 45:127-135.

— — - - J.P. WARd, AND B.E. STROHMEYER. 2005. Home range, habitat use, survival, and fecundity of Mexican Spotted Owl in the Sacramento Mountains, New Mexico. Southwest. Nat. 50:323-333.

Gutiérrez, R.J., A.B. Franklin, and W.S. Lahaye. 1995. Spotted Owl (Strix occidentalis). In A. Poole and F. Gill [EDs.], The birds of North America, No. 179. The Academy of Natural Sciences, Philadelphia, PA and The American Ornithologists' Union, Washington, DC U.S.A.

Hintze, L.F. 1988. Geologic history of Utah. Univ. Press and Department of Geology, Brigham Young Univ., Provo, UT U.S.A.
LeE, J.E., G.C. White, R.A. Garrott, R.M. BartmanN, AND A.W. AlldREDGE. 1985. Assessing accuracy of a radiotelemetry system for estimating animal locations. J. Wildl. Manage. 49:648-663.

LENTH, R.V. 1981. On finding the source of a signal. Technomet. 23:149-154.

NAms, V.O. 1990. Locate II user's guide. Pacer Computer Software, Truro, Nova Scotia, Canada.

OTIS, D.L. AND G.C. White. 1999. Autocorrelation of location estimates and the analysis of radiotracking data. $J$. Wildl. Manage. 63:1039-1044.

Rinkevich, S.E. AND R.J. GutiéRREZ. 1996. Mexican Spotted Owl habitat characteristics in Zion National Park. J. Raptor Res. 30:74-78.

SwiHart, R.K. AND N.S. SLAdE. 1985. Testing for independence of observations in animal movements. Ecology 66:1176-1184.

Thornbury, W. 1965. Regional geomorphology of the United States. John Wiley and Sons, New York, NY U.S.A.

USDI. 1995. Recovery plan for the Mexican Spotted Owl. U.S. Fish and Wildlife Service, Albuquerque, NM U.S.A.

White, G.C. AND R.A. GARrott. 1990. Analysis of wildlife radio tracking data. Academic Press, Inc., New York, NY U.S.A.

Willey, D.W. 1995. Mexican Spotted Owls in canyonlands of the Colorado plateau. Pages 330-331 in E.T. LaRoe, G.S. Farris, C.E. Puckett, P.D. Doran, and M.J. Mac [EDS.], Our living resources: a report to the nation on the distribution, abundance, and health of U.S. plants, animals, and ecosystems. U.S. Department of the Interior, National Biological Service, Washington, DC U.S.A.

- 1998. Movements and habitat characteristics of Mexican Spotted Owls in the canyonlands of Southern Utah. Ph.D. dissertation. Northern Arizona Univ., Flagstaff, AZ U.S.A.

AND VAN RIPER III. 2000. First-year movements by juvenile Mexican Spotted Owls in the canyonlands of Utah. J. Raptor Res. 34:1-7.

WORTON, B.J. 1989. Kernel methods for estimating the utilization distribution in home-range studies. Ecology 70:164-168.

Zwank, P.J., K.W. Kroel, D.M. Levin, G.M. Southward, AND R.C. Romme. 1994. Habitat characteristics of Mexican Spotted Owls in southern New Mexico. J. Field Ornithol. 65:324-334.

Received 28 April 2006; accepted 8 December 2006 Associate Editor: James W. Watson 